\title{
Chapter 30 \\ Modeling a Complex Production Line Using Virtual Cells
}

\author{
Luís Pinto Ferreira, Enrique Ares Gómez, Gustavo Peláez Lourido, \\ and Benny Tjahjono
}

\section{Introduction}

Simulation is considered one of the worthwhile tools that can be used to analyze the behavior of a production line especially when the application of analytical methods proves to be difficult $[1,2]$. The complexity of production systems justifies the use of simulation techniques in the detection of critical problems during the design or redesign of new systems, or in the diagnosis of existing systems in order to improve their performance [3]. According to (Sadowski) in Torbörn Ilar [4], a successfully developed simulation project is one which produces useful information, within an adequate time-span, to support decision-making.

The work described in this chapter consists of the development of a simulation model based on a real case and is aimed at a very specific class of production lines, with a four closed loop network configuration, used commonly in the automotive sector. This study is an extension of the work of Resano and Pérez [5, 6], who designed one of the first analytical models for an assembly line in the vehicle sector as a network of four closed loops of machines, decoupled by intermediate buffers formed by conveyors. They consider that machines process pallets, which are not univocally related to each other. The use of simulation model presented in this

\footnotetext{
L.P. Ferreira $(\square)$

Escola Superior de Estudos Industriais e de Gestão (Technical Scientific Unity of Industrial Engineering and Production), Instituto Politécnico do Porto, Porto, Portugal e-mail: Luispintoferreira@eu.ipp.pt
}

\author{
E.A. Gómez • G.P. Lourido \\ Área Ingeniería de los Procesos de Fabricación, Universidad de Vigo, Vigo, Spain \\ e-mail: enrares@uvigo.es; gupelaez@uvigo.es \\ B. Tjahjono \\ Manufacturing Department, Cranfield University, Cranfield, UK \\ e-mail: b.tjahjono@cranfield.ac.uk
}


chapter, the blocking and starvation phenomena of a complex production line can be analyzed. These models also consider the proportion of four- and two-door cars between the door disassembly and assembly stations.

\section{Conceptual Modeling Based on Virtual Cells}

The concept of virtual cells (or also known as reconfigurable cells) can be conceptually used in the modeling of a production line. The concept of the virtual cell was first introduced by McLean et al. [7] in the context of the development of control software for an automated production line of small lots of parts. A virtual cell stems from the purely logical integration, and not a physical one, of the resources needed for the manufacture of a product [8]. A virtual cell is the logical grouping of resources within a controller. When an order is placed (which determines a set of work stations to manufacture a specific product), the virtual cell controller takes on the control of those stations and makes communication and iteration among them possible [7, 9-11]. The virtual cell differs from a traditional production cell in two aspects: the concept of machine sharing and the physical layout of the machines. In the traditional production system, a family of products is expected to be processed entirely within a dedicated cell of machines. Any movement of parts between the different cells is not advisable. Thus, common problems are the duplication of equipment and its low rate of usage. The deployment of the machinery influences all of the production activities. Therefore, any changes in the product to be manufactured with the purpose of meeting the market demand imply changing the line layout, which consequently impacts the time expenditure and its associated costs $[12,13]$. In contrast, virtual cells are configured according to the dynamic and temporary allocation of the workstations so as to process a specific product [8]. In a virtual cell, the position of machinery is not critical [12]. Thus, according to Khilwani et al. [14], virtual cells have taken on a relevant role in cases of variable demand as well as in those where there are changes in the structure of manufactured products. According to Baykasoglu [15], the main difference between a virtual cell and the physical manufacturing cell resides in the dynamic nature of the former. In the case of physical cells, the location of work stations is fixed and can be perfectly identifiable. This does not happen with virtual cells since they will vary according to the requirements at hand. According to Ares et al. [16], a virtual cell is any production scenario, from the lowest levels in a manufacturing hierarchy (for example, a CNC machine) to the highest (for example, a factory). Its internal organization allows for the manufacture of different types of products, as well as that of establishing significant parameters in its production capacity.

Figure 30.1 shows an example of how three virtual cells can be grouped in a jobshop production, in which three types of products are processed and where each of the geometric features belonging to the system represent machines that enable operations to be undertaken according to the flow of each product [17]. 

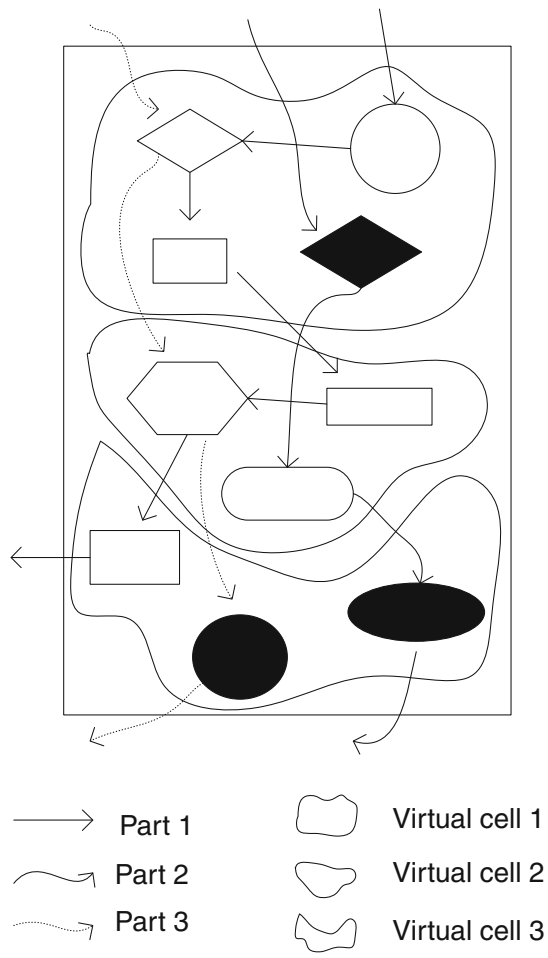

Fig. 30.1 Line of virtual cells based on job-shop production (adapted from [17])

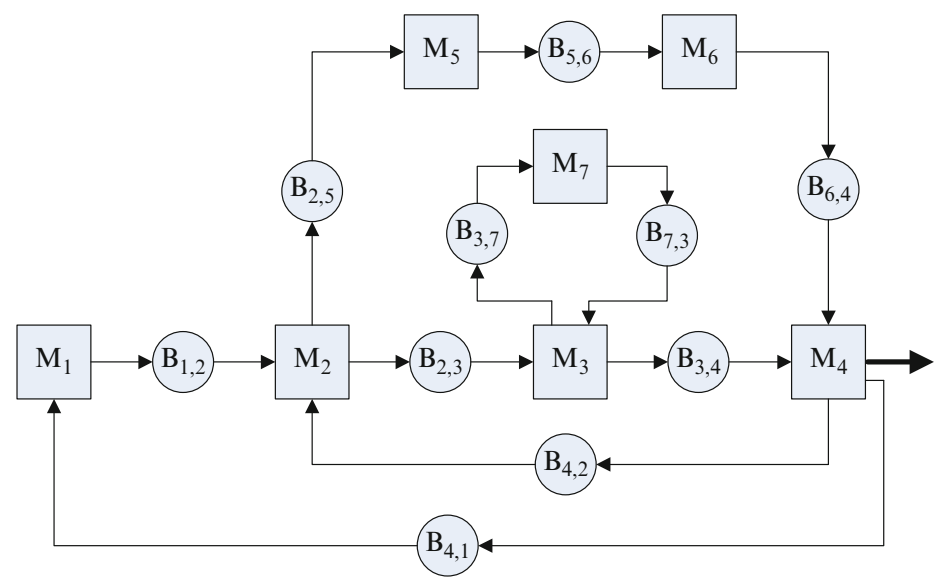

Fig. 30.2 Main automobile assembly line and subassembly lines $[5,6]$ 


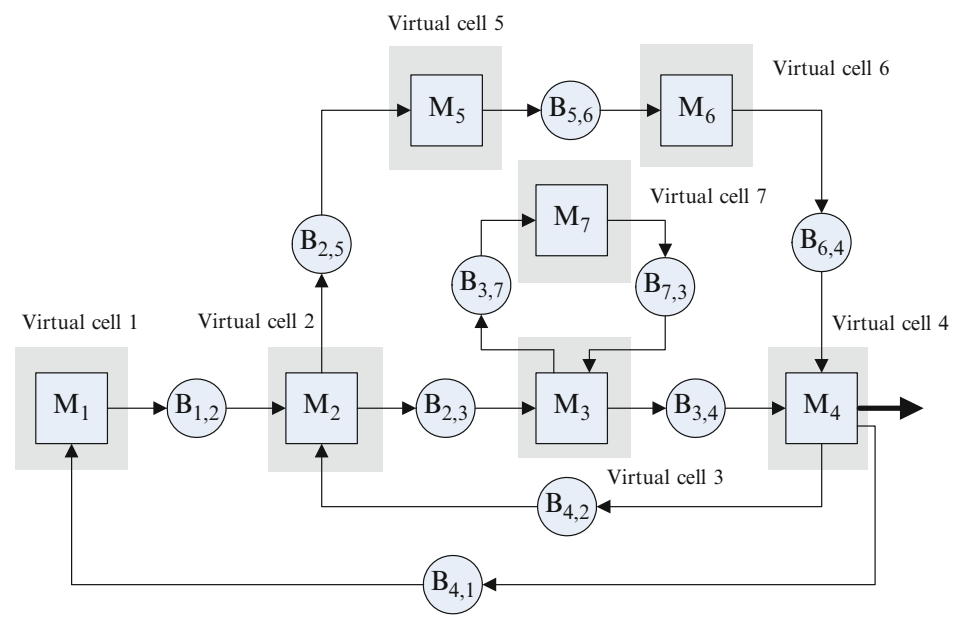

Fig. 30.3 Modeling of the automobile assembly line using seven virtual cells [18]

Figure 30.2 is a representation of the main automobile production line used in this research, along with the door and front axle subassembly lines. The configuration exhibits a network of four closed loops of machines (M) and intermediate buffers (B) connected by conveyors. The cycle time for each machine is fixed and deterministic.

The total number of the car bodies, door and front axle assembly pallets stored in each of the intermediate buffers of the three first closed loops remain constant at any time and are defined by (30.1)-(30.3) [5, 6].

$$
\begin{gathered}
n_{12}+n_{23}+n_{34}+n_{41}=237 \\
n_{25}+n_{56}+n_{64}+n_{42}=450 \\
n_{37}+n_{73}=138
\end{gathered}
$$

The fourth closed loop defines the relationship between the number of pallets with car doors in different subassembly states and the number of pallets of cars with disassembled doors using an external variable $(x)$, according to (30.4). This variable represents the four-door car ratio between the door disassembly stations, located at $\mathbf{M}_{2}$ and the door assembly stations, located at $\mathbf{M}_{4}$. This variable can have values between 0 and 1 .

$$
n_{25}+n_{56}+n_{64}+60=\left(216+n_{23}+n_{34}\right)(1+x)
$$

Figure 30.3 shows the automobile assembly line analyzed in this study. As with Resano and Pérez [5, 6], seven virtual cells were constructed so as to better understand the trajectories of the state of the intermediate buffers formed by 


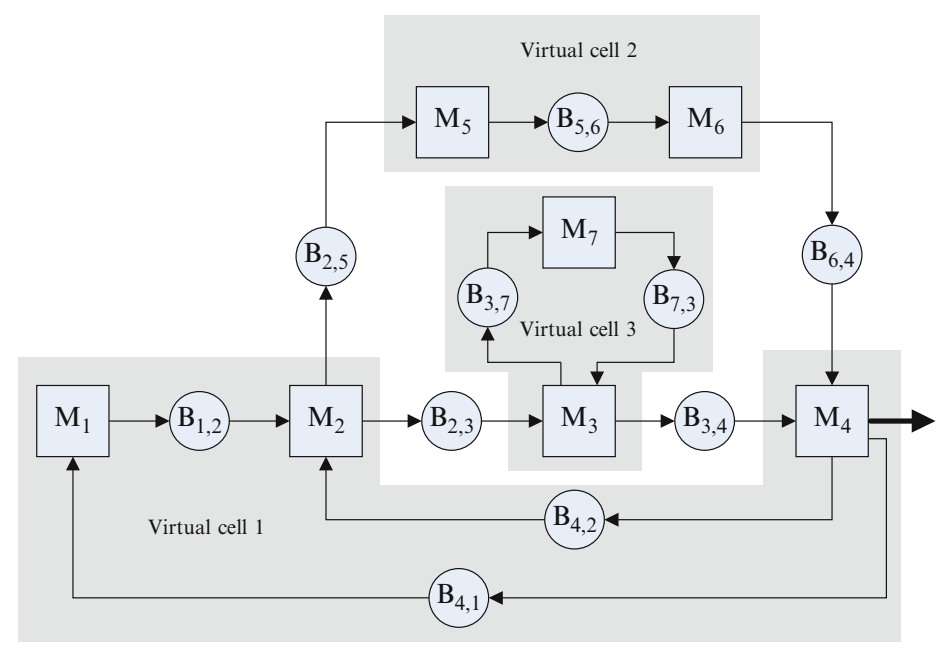

Fig. 30.4 Modeling of the automobile assembly line based on three virtual cells [18]

conveyors, positioned between each virtual cell and thus ensuring supply to the cells and avoiding starvation. These virtual cells are represented by each of the machines (M) presented in Fig. 30.3. In the automobile production line being analyzed, each of these constitutes a set of different types of stations (e.g. manual stations, automatic stations, semiautomatic stations), which are logically grouped with the purpose of undertaking a specific set of tasks [18]. For this study, this modeling of line configuration can be used to develop a decision-support system based on a discrete event simulation model for a multistage multiproduct automobile production line.

Another line configuration modeling option based on three virtual cells could be used for the analysis and optimization of the automobile assembly line being studied, as is presented in Fig. 30.4.

Another modeling example based on the concept of virtual cells is presented in Fig. 30.5, in which the automobile assembly line is structured on the basis of two virtual cells.

The main advantage of virtual cells is that they facilitate modeling of a complex network system, in a system of multistage lines, where each stage (see Fig. 30.6) is a virtual cell $M_{j}$, its entry and exit buffers are $B_{i j}$ and $B_{i, j+1}$, and $Q_{i j}$ is the supply flow of parts, from buffer $B_{i j}$ to the virtual cell $M_{j}[16,17,19-21]$.

Virtual cell $M_{j}$ can process various types of parts. The entry of parts on cell $M_{j}$ is undertaken sequentially and its rate is determined by the production strategy being considered. The $Q_{i j}(t)$ represents the supply flow, which crosses virtual cell $M_{j}$, from the entry buffer $B_{i j}$, to the exit buffer $B_{i, j+1}$. If the line consists of m virtual cells and each cell processes $n$ parts, there will then be $n \times m$ flows in the entire system. The flow of parts $Q_{i j}(t)$ is expressed by (30.5), where index $i$ represents the 


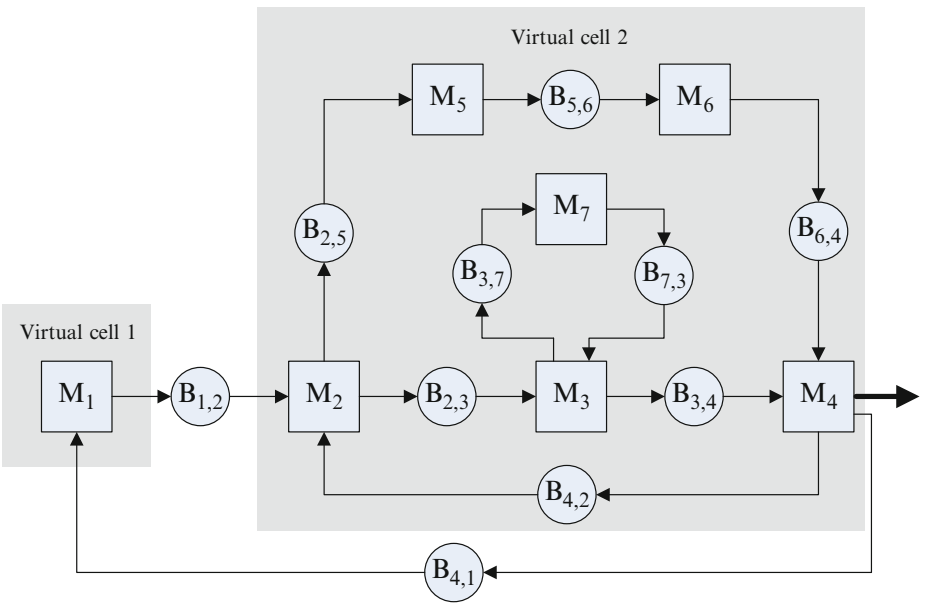

Fig. 30.5 Modeling of the automobile assembly line using two virtual cells [18]

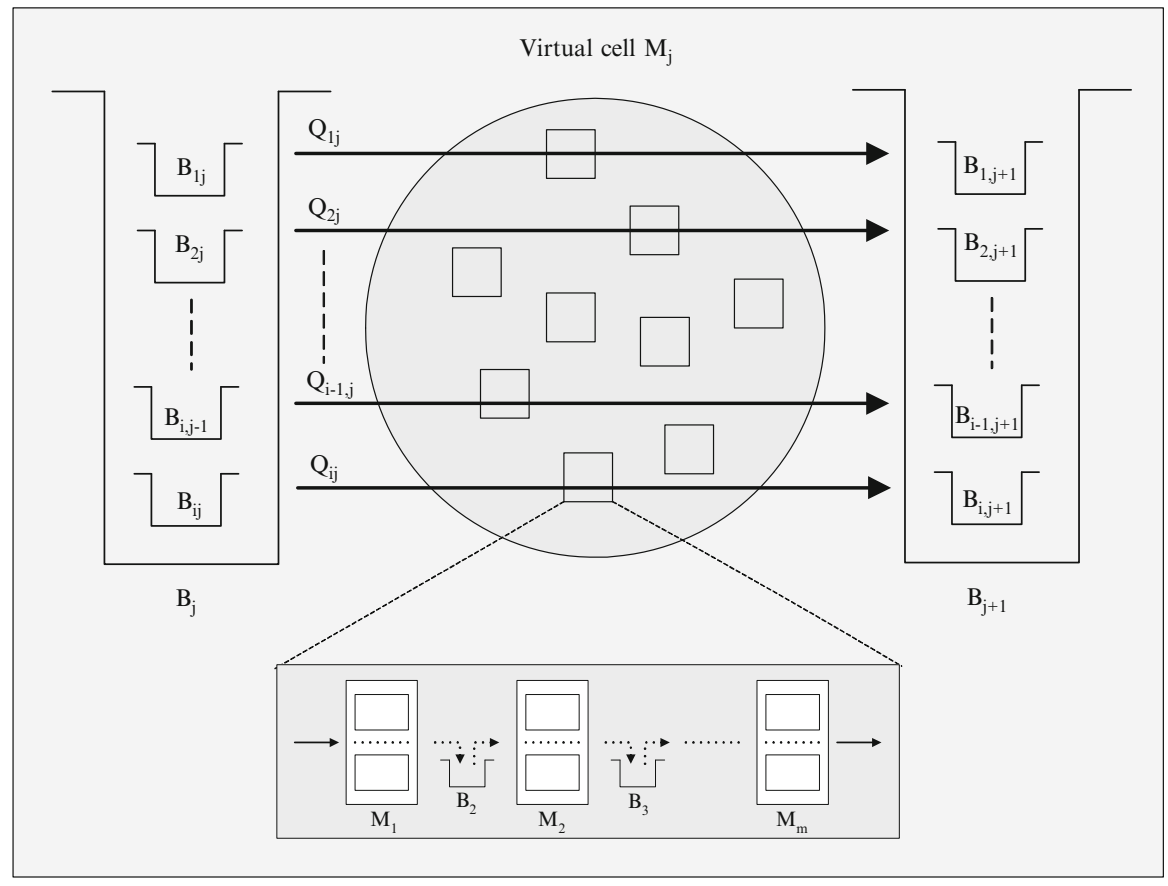

Fig. 30.6 Stage of a flexible cell line (adapted from [16, 19, 22]) 
type of part, and index $j$ indicates the order that the virtual cell being analyzed occupies on the line $[16,21,23,24]$.

$$
\begin{gathered}
Q_{i j}(t)=S_{i j} \times V_{i j}(t)=\left(1 / T_{i j}\right) \times V_{i j}(t), \quad i=1, \ldots, n ; \\
\text { subject to: } \sum_{i=1}^{n} V_{i j}(t) \leq 1
\end{gathered}
$$

where:

- $T_{i j}$ represents the processing time for each part ( $T_{i j} \in \mathrm{IR}$, is known and fixed);

- $S_{i j}$ translates maximum production flow $\left(S_{i j}=1 / T_{i j}\right)$;

- $V_{i j}(t)$ represents the dedicated coefficient for each virtual cell $M_{j}$ for each type of part $i$, in every moment in time $t$. The $V_{i j}(t)$ is obtained in accordance with the control strategy selected a priori $\left(V_{i j}(t) \in \mathrm{IR}, 0 \leq V_{i j}(t) \leq 1\right)$.

The space restrictions in each of the buffers $B_{i j}$ and $B_{i, j+1}$, represented in Fig. 30.6, require one to balance the flows in order to prevent line blockages. Considering that the variable $X_{i j}(t)$ indicates the instant value for the level of storage on each of the buffers, this variable will represent the state of the buffers at every moment. Thus, if $b_{i j}$ represents the maximum capacity for buffer $B_{i j}$, variable $X_{i j}(t)$ can be expressed by (30.6).

$$
0 \leq X_{i j}(t) \leq b_{i j}
$$

The evolution over time of the state variable $X_{i j}(t)$, which will be represented by $Y_{i j}(t)$, is provided by the difference between the supply flow of parts to $B_{i j}, Q_{i j-1}(t)$ and the supply flow of parts from buffer $B_{i j}$ to the $M_{j}$ cell, which is $Q_{i j}(t)$. Thus, $Y_{i j}(t)$ can be represented by (30.7). Therefore, if $Y_{i j}(t)>0$, this means that the buffer is filling up; if $Y_{i j}(t)<0$, this means that the buffer is becoming empty and if $Y_{i j}(t)=0$, one can consider the flows to be balanced $\left(X_{i j}(t)=\right.$ constant $)[16,17$, $19,21,24,25]$.

$$
Y_{i j}(t)=Q_{i j-1}(t)-Q_{i j}(t)
$$

The three running modes or buffer states for $M_{j}$ cells or for their $B_{i j}$ can be defined as:

- Full output mode (on $M_{j-1}$ ). If buffer $B_{i j}$ is full, the parts being manufactured on cell $M_{j-1}$ cannot be placed here since this will cause the blockage of cell $M_{j-1}$. In this case, the instant value of the supply level can be expressed as $X_{i j}(t)=b_{i j}$.

- Null input mode (on $M_{j}$ ). If buffer $B_{i j}$ is empty, there are no parts to supply cell $M_{j}$, causing a situation of starvation on $M_{j}$. In this case, the instant value for the storage level is provided by the condition: $X_{i j}(t)=0$.

- Normal mode. Here, the buffer is neither full nor empty. In this running mode, the value of $X_{i j}(t)$ is provided by the following expression: $0<X_{i j}(t)<b_{i, j+1}$. 


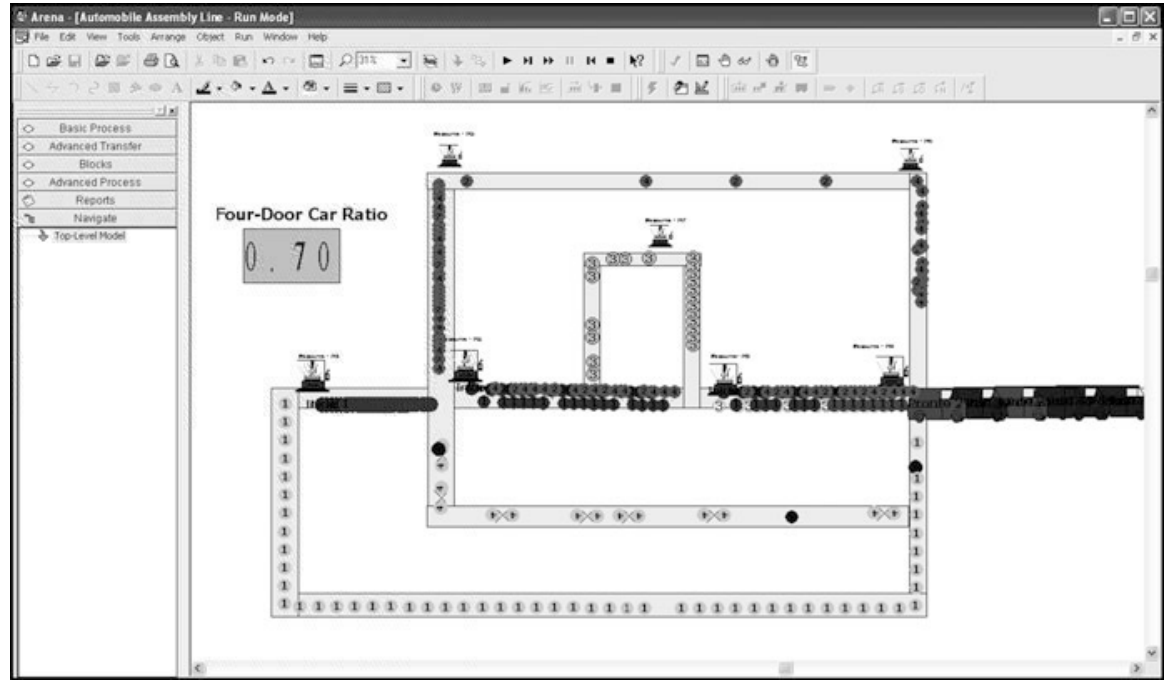

Fig. 30.7 Simulation model for $x=0.7$

\section{Characteristics of the Decision-Making Support System Developed}

In the context of this project, all the work was developed in an Arena ${ }^{\circledR}$ simulation environment [26]. Its simulation language constitutes a visual and flexible programming tool, directed at the object, since it simultaneously combines the construction of simulation models with the integration of different commonly used languages: Visual Basic, $\mathrm{C}, \mathrm{C}^{++}$. This language is based on the Siman simulation language [18, 27, 29].

The purpose of the use of an Arena simulation environment was that of enabling the production engineer to evaluate the performance of the automobile assembly line, through the variation of different parameters, thus contributing to an improved specification, characterization and definition of the most efficient control system. With this objective in mind, a support system for decision-making was developed; this enables the automatic generation of different simulation models. In the initial stage of simulation, the user is able to interact with the system to be developed, through the introduction of various parameters such as [18, 28, 29]: the four-door car ratio $(x)$; the processing time for each machine; the production sequence in accordance with each type of car (two- or four-door); the speed and length of the intermediate buffers formed by conveyors; simulation time; the number of pallets circulating on the first three closed loops. Figure 30.7 shows an example of a screenshot of the simulation model developed in Arena ${ }^{\circledR}$ incorporating the abovementioned parameters. 


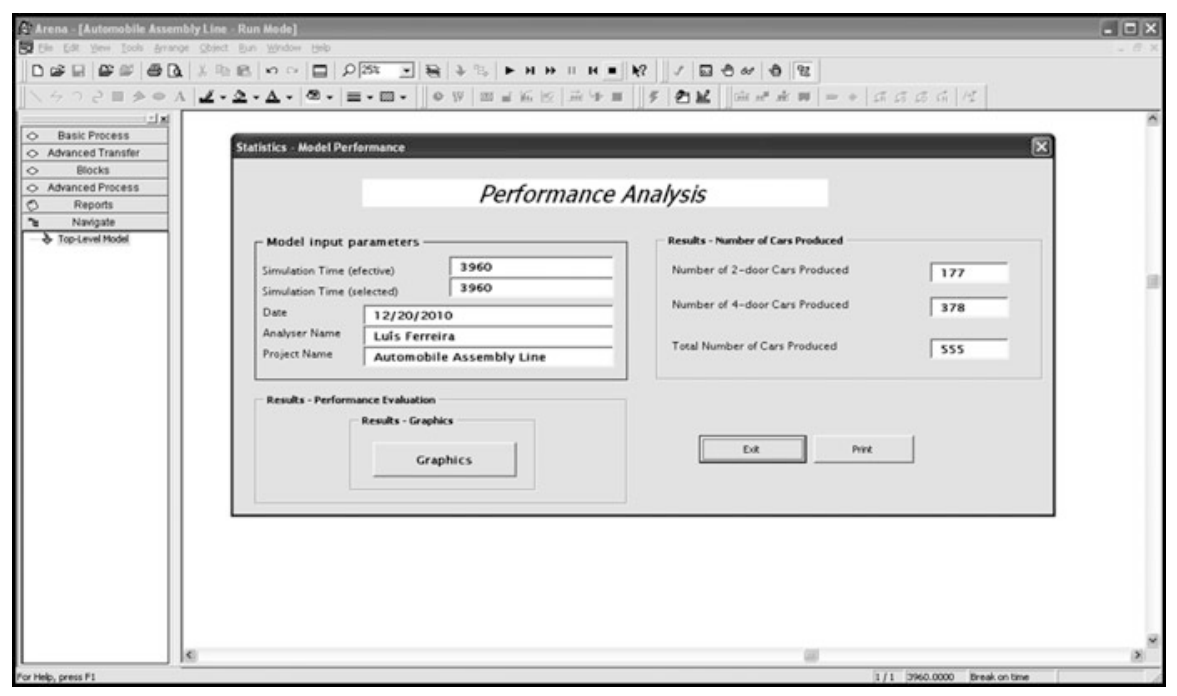

Fig. 30.8 Main selected input parameters

Another contribution made by this study is the automatic report generator in the simulation environment; this presents information on the main performance indexes of the simulated models, using graphic visualization, which required the integration of various applications in the Arena simulation environment, such as: Visual Basic for Applications (VBA), Visual Basic (VB), Microsoft Access (Database), and Crystal Report (Graphics Edition). So at the end of each simulation, a summary of the main selected input parameters is presented to the user (see Fig. 30.8). From this interface, the user can access to another module (see Fig. 30.9), where he or she has the opportunity to edit, in the form of graphics, information concerning the simulated model's performance. In this context, it is worth highlighting the visual aspects of the graphics produced (two examples are presented in Figs. 30.10 and 30.11), which allow the user to have a better perception of the performance of the simulated models. From among those considered, the following performance indicators are highlighted: machine usage levels; number of cars for each of the types produced; number of operations undertaken on each of the machines; production time/vehicle; relationship between the time cycle of each machine and the number of pallets on each upstream buffer.

\section{Validation of the Simulation Model Proposed}

In Resano and Pérez [5, 6], the incompatibility between (30.2) and (30.4) was demonstrated. These define the sum of the number of pallets on the intermediate buffers, which constitute the second and fourth closed loop, with some of the 


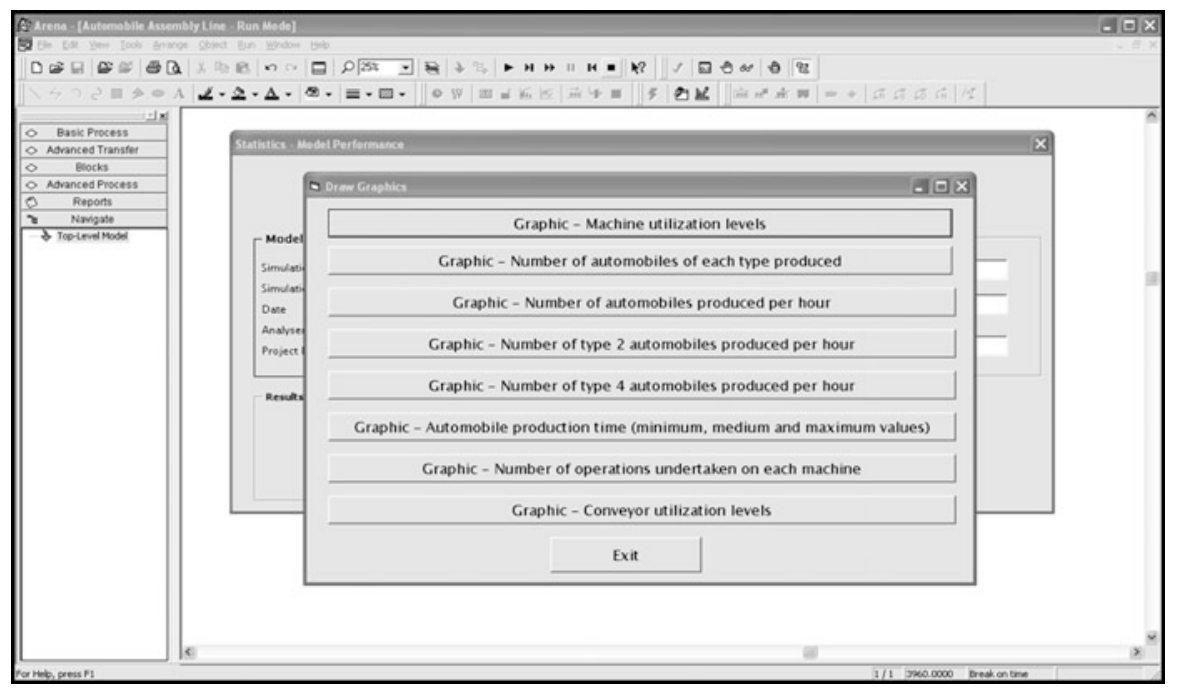

Fig. 30.9 Simulation results (graphics)

\section{Conveyor utilization levels}

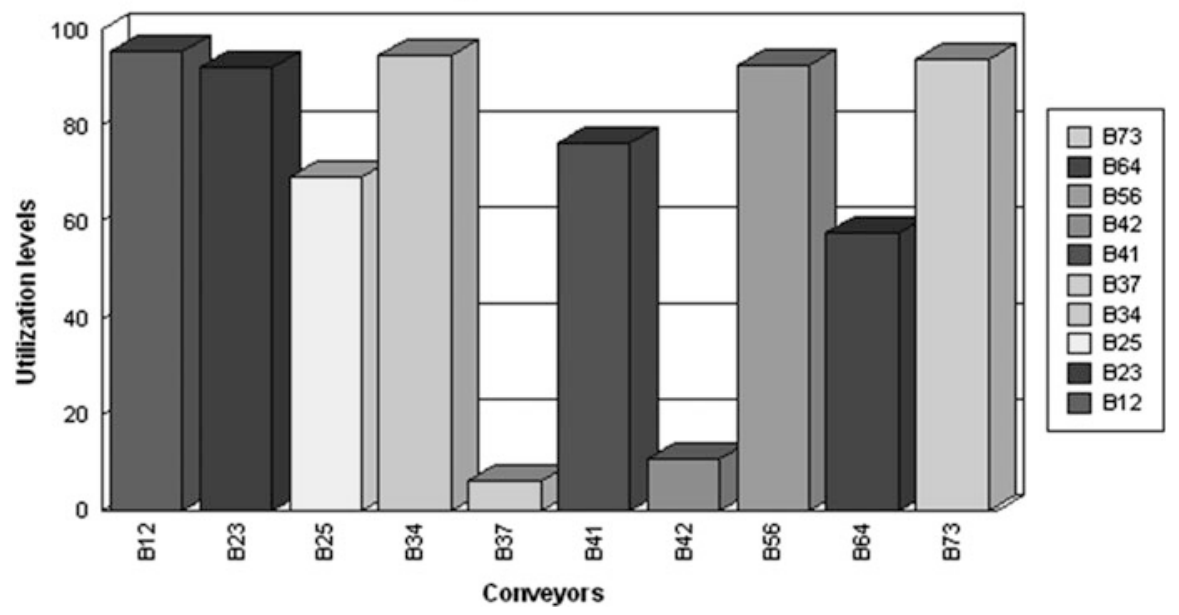

Fig. 30.10 Conveyor utilization levels

maximum and minimum capacities of the corresponding intermediate buffers, for the specific values of variable $x$. This incompatibility reveals that the automobile assembly line cannot operate in practice for $x<0.37$, in both the stationary and transitory regimes, as well as for $x>0.97$, in the stationary regime. As with any simulation project, an important phase is the validation of the model constructed; 


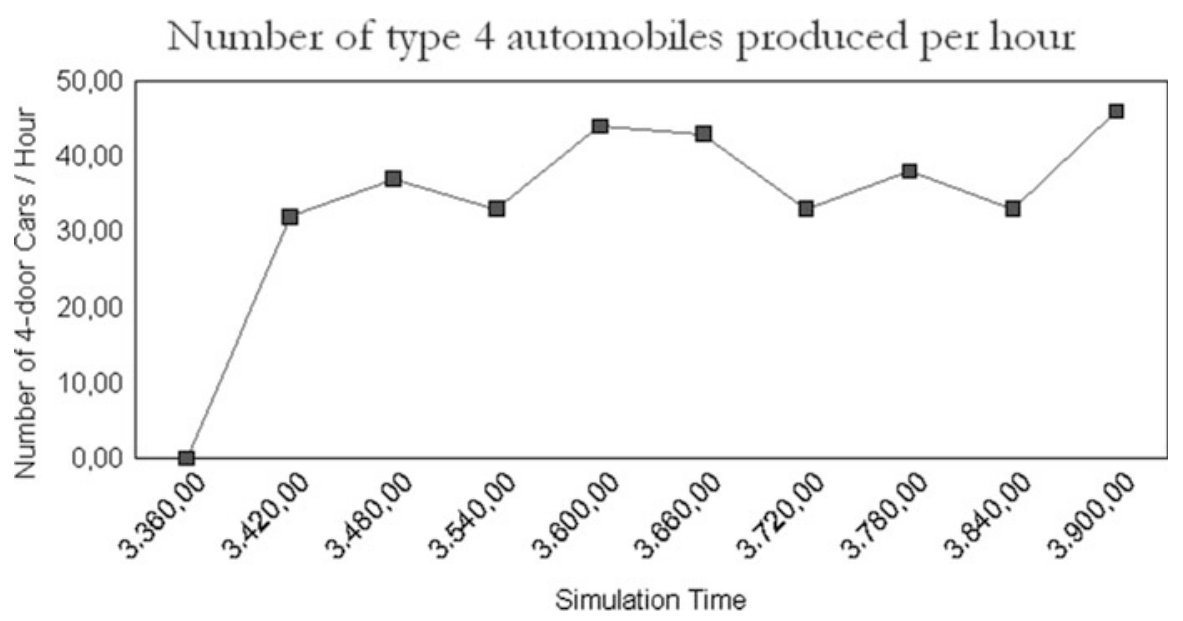

Fig. 30.11 Number of type 4 automobiles produced per hour

this ensures that it is a true representation of reality and can then be used for decision-making. Through the simulation model developed in the context of this study, and for the automobile production line being analyzed, one also verified that the system did not function for the values of $x<0.37$ and $x>0.97$, due to the phenomena of blockage and starvation occurring on the machines integrating the analyzed model. In the same way, one also noticed that, once the minimum buffer capacity mentioned in Resano and Pérez [5, 6] was reached, a continuous supply of transport and assembly pallets to machines was assured. In the context of this work, the validation of the simulation model proposed was confirmed, on the basis of these two presuppositions [18, 28, 29].

\section{Conclusion}

In this paper, an automobile assembly line and different preassembly lines were modeled as a network of four closed loop machines and intermediate buffers formed by conveyors, constituting a configuration which is widely used in these kinds of assembly line. A representative model of this line was developed with the purpose of providing the production engineers with a better understanding and assessment of its performance; it represents each moment in the state of the system and its evolution over time, thus allowing for improved communication between the model and the user. In fact, the visual components in the model allows for a clear understanding of the decision-making agents who will eventually use them, since they will be able to view the interaction that occurs between the entities which make up the model, allowing for a better understanding of the simulation results. 
This study has contributed to the importance of simulation in the development of a computer-based model and virtual environments, which is a reproduction of the behavior of many real systems.

\section{References}

1. Benedettini O, Tjahjono B (2009) Towards an improved tool to facilitate simulation modelling of complex manufacturing systems. Int J Adv Manuf Technol 43:191-199

2. Papadopoulos CT, O‘Kelly MEJ, Vidalis MJ, Spinellis D (2009) Analysis and design of discrete part production lines. In: Springer optimization and its applications, vol 31. Springer, New York. ISBN 978-0-387-89493-5

3. Ferreira JJP (1995) Suporte do Ciclo de Vida dos Sistemas Integrados de Fabrico através de Modelos Executáveis sobre Infra-estruturas de Integração. Tese de Doutoramento em Engenharia Electrotécnica e de Computadores, Faculdade de Engenharia da Universidade do Porto

4. Ilar T (2008) Production simulation as a management tool. Doctoral Thesis, University of Technology, Luleå, ISSN: 1402-1544

5. Resano Lázaro A (2007) Análisis Funcional y Optimización de la Distribuición en Planta de una Línea de Ensamblaje de Automóviles. PhD Thesis, Departamento de Ingeniería Mecánica

6. Resano Lázaro A, Luis Pérez CJ (2008) Analysis of an automobile assembly line as a network of closed loops working in both, stationary and transitory regimes. Int J Prod Res 46 (17):4803-4825, ISSN: 1366-588X

7. Mclean CR, Bloom HM, Hopp TH (1982) The virtual manufacturing cell. In: Proceedings of fourth iFAC/IFIP conference on information control problems in manufacturing technology, USA, pp 105-111

8. Alves AC (2007) Projecto Dinâmico de Sistemas de Produção Orientados ao Produto. Tese de Doutoramento em Engenharia de Produção e Sistemas, Universidade do Minho

9. Drolet J, Abdulnour G, Rheault M (1996) The cellular manufacturing evolution. Comp Ind Eng 31(1-2):139-142

10. Mak KL, Wang XX (2002) Production scheduling and cell formation for virtual cellular manufacturing systems. Int J Adv Manuf Technol 20:144-152

11. Nomden G, van der Zee D-J (2008) Virtual cellular manufacturing: configuring routing flexibility. Int J Prod Econ 112(1):439-451

12. Ko K-C, Egbelu PJ (2003) Virtual cell formation. Int J Prod Res 41(11):2365-2389

13. Fung RYK, Liang F, Jiang Z, Wong TN (2008) A multi-stage methodology for virtual cell formation oriented agile manufacturing. Int J Adv Manuf Technol 36:798-810

14. Khilwani N, Ulutas BH, Attila Islier A, Tiwari MK (2009) A methodology to design virtual cellular manufacturing systems. J Intell Manuf, Springer, 22(4): 533-544

15. Baykasoglu A (2003) Capability-based distributed layout approach for virtual manufacturing cells. Int J Prod Res 41(11):2597-2618

16. Ares Gómez E, Peláez Lourido G, Gómez Lourido R (1990) Modelo Dinamico para la Evaluacion de la Eficiencia de Estrategias de Produccion en Ambiente CIM. In: Anales de Ingeniería Mecánica, Revista de la Asociación Española de Ingeniería Mecánica, Diciembre 1990

17. Peláez Lourido G (1999) Arquitectura y Modelo integral de un Sistema de Fabricación multietapa/multiproducto. Thesis Doctoral, Universidade de Vigo

18. Ferreira LP, Ares Gómez E, Peláez Lourido G, Tjahjono B (2011) Optimization of a multiphase multiproduct production line based on virtual cells. In: Lecture notes in engineering and computer science: Proceedings of the world congress on engineering (WCE2011), London, 6-8 July 2011, pp 616-621 
19. Ares Gómez JE (1986) Estructura Jerárquica de Metodologías para la Implantación y Gestión de Sistemas de Fabricación Flexible. Tesis Doctoral, Universidad de Santiago de Compostela

20. Villa A, Ares E (1988) In: Mital A (ed) Methodology to evaluate dispatching rules for a manufacturing line by discrete event dynamic model, vol 6. Elsevier, Amsterdam, pp 485-491. ISBN 0-4444-42929

21. Ares Gómez JE, Pérez Garcia JA, Peláez Lourido GC (1992) Diseño de Células en el LayOut de un Taller y Análisis del Flujo Multi-Etapa/Multi-Producto en Un Entorno CIM. In: X Congreso Nacional de Ingeniería Mecánica, Revista de la Asociación Española de Ingeniería Mecánica, Septiembre 1992

22. Ares E, Peláez G (1997) Integración de línea y célula flexibles en un modelo jerárquico para la planificación y programación de la producción. In: XII Congreso Nacional de Ingeniería Mecánica, Anales de Ingeniería Mecánica, Revista de la Asociación Española de Ingeniería Mecánica, Febrero 1997

23. Ares Gómez E, Ollero A, Arcostanzo M, Villa A (1987) Planificación de la producción en sistemas de fabricación en estaciones interconectadas en red. In: Anales de Ingeniería Mecánica, Revista de la Asociación Española de Ingeniería Mecánica, Diciembre 1987

24. Villa A, Fiorio G, Ares E (1987) In: Kusiak A (ed) Production planning and control in multistage multi-product systems. Elsevier, Amsterdam, pp 247-257. ISBN 0-444-70272-5

25. Villa A, Ares Gómez JE (1987) A methodology to analyze workshop lines by discrete event dynamic models. In: Mital A (ed), IXth International conference on production research, vol I, Cincinnati, pp 2072-2078

26. David Kelton W, Sadowski RP, Sturrock DT (2007) Simulation with arena, 4th edn. McGrawHill, New York. ISBN 978-0-07-110685-6

27. Takus DA, Profozich DM (1997) ARENA Software Tutorial. In: Proceedings of 1997 winter simulation conference, Atlanta, pp 541-544

28. Ferreira LP, Ares Gómez E, Peláez Lourido GC, Quintas JD, Tjahjono B (2011) Analysis and optimisation of a network of closed-loop automobile assembly line using simulation. Int J Adv Manuf Technol, Springer, 59:351-366

29. Ferreira LP, Ares Gómez E, Peláez Lourido G, Salgado M, Quintas JD (2011) Analysis on the influence of the number of pallets circulating on an automobile closed-loop assembly line. Int $\mathrm{J}$ Adv Eng Sci Technol 2(2):119-123 